\title{
Kemampuan Komunikasi Matematis Siswa Dalam Menyelesaikan Soal PISA Konten Space And Shape
}

\author{
Mohammad Kholil ${ }^{1}$, Eric Dwi Putra ${ }^{2}$ \\ ${ }^{1}$ Institut Agama Islam Negeri (IAIN) Jember, \\ ${ }^{2}$ Institut Keguruan dan Ilmu Pendidikan (IKIP) PGRI Jember, \\ muad.kholil@gmail.com
}

\begin{abstract}
Abstrak
Komunikasi matematis merupakan salah satu hal penting dalam menyelesaikan masalah pada studi PISA. Komunikasi matematis adalah kemampuan mengekspresikan ide-ide matematika secara koheren kepada teman, guru, dan lainnya melalui bahasa lisan maupun tulisan yang disertai dengan penjelasan dan justifikasi. Karena pentingnya kemampuan komunikasi yang dimiliki oleh siswa, maka muncul gagasan untuk menganalisis tingkat kemampuan komunikasi matematis siswa dalam menyelesaikan soal PISA konten space dan shape. Tujuan penelitian ini adalah untuk mendeskripsikan kemampuan komunikasi matematis siswa dalam menyelesaikan soal PISA konten space and shape. Penelitian ini menggunakan pendekatan kualitatif, dengan jenis penelitian deskriptif. Hasil penelitian ini menunjukkan bahwa 1) siswa dengan kemampuan matematika tinggi memiliki kemampuan komunikasi matematis sangat baik dengan hampir memenuhi seluruh indikator; 2) siswa yang memiliki kemampuan matematika sedang memiliki komunikasi matematis baik dengan memenuhi indikator hingga dapat menjelaskan suatu permasalahan dengan baik.
\end{abstract}

Kata Kunci: komunikasi matematis, Soal PISA, space and shape

\begin{abstract}
Mathematical communication is one of the important things in solving problems on the PISA study. Mathematical communication is the ability to express mathematical ideas coherently to friends, teachers, and others through spoken and written language accompanied by explanations and justifications. Because of the importance of communication skills possessed by students, then the idea arises to analyze the level of mathematical communication skills of students in solving PISA questions of space and shape content. The purpose of this study is to describe the mathematical communication skills of students in solving PISA questions on space and shape content. This research uses a qualitative approach, with descriptive research type. The results of this study indicate that 1) students with high mathematical abilities have excellent mathematical communication skills with almost all the indicators; 2) students who have mathematical abilities are having good mathematical communication by meeting the indicators so that they can explain a problem well.
\end{abstract}

Kata Kunci: Mathematical communication, PISA question, space and shape 


\section{PENDAHULUAN}

Salah satu cara yang dilakukan oleh Negara maju untuk meningkatkan kualitas pendidikannya yaitu dengan melakukan studi Programme for International Student Assesment (PISA). Studi PISA merupakan studi tentang program penilaian siswa bertaraf internasional yang diselenggarakan oleh organisasi Organization for Economic Coorporation and Development (OECD) yang berkedudukan di Paris, Prancis. Studi ini merupakan studi yang dikembangkan oleh beberapa negara maju yang tergabung sebagai anggota OECD serta dilaksanakan setiap tiga tahun sekali (OECD, 2017).

Indonesia tercatat mengikuti studi PISA sejak tahun 2000 hingga pada tahun 2018. Pada tahun 2000, Indonesia mendapat peringkat 39 dari 41 negara yang mengikuti dengan perolehan skor 367 untuk studi literasi matematika. Selanjutnya pada tahun 2003, studi PISA diikuti oleh 41 negara dan Indonesia mendapatkan peringkat ke-38 dengan skor literasi matematika 360. Tahun 2006, 2009 dan 2012, Indonesia secara berturut-turut mendapatkan peringkat ke-50 dari 57 negara, peringkat ke-60 dari 65 negara dan peringkat 64 dari 65 negara. Terakhir pada tahun 2015, rata-rata kemampuan literasi matematika Indonesia adalah 386 dimana rata-rata tersebut masih tergolong rendah dibandingkan dengan ratarata literasi lainnya(OECD, 2016). Hal ini merupakan hasil yang belum maksimal bagi Indonesia karena dari beberapa tahun mengikuti studi PISA Indonesia hanya mendapatkan peringkat rata-rata skor untuk sains, membaca, dan matematika berada di peringkat 62, 61, dan 63 dari 69 negara. Terakhir pada tahu 2015, Indonesia berada pada peringkat 62 dari 70 negara yang mengikuti dengan perolehan skor dibawah 450 dan termasuk dalam Negara-negara yang mendapatkan skor terendah (OECD, 2019).

Tiga komponen besar yang diidentifikasi dalam studi PISA yaitu konten, proses dan konteks. Konten PISA dibatasi pada 4 konten yaitu : (1) Change and
Relationship (Perubahan dan Hubungan), (2) Space and Shape (Ruang dan Bentuk), (3) Quantity (Kuantitas), (4) Uncertainty and Data (Ketidakpastian dan Data) (OECD, 2019). Dalam penelitian ini menggunakan konten Space and Shape yang melibatkan pola, sifat dari objek, posisi dan orientasi, representasi dari objek, pengkodean informasi visual, navigasi, dan interaksi dinamik yang berkaitan dengan bentuk rill. Kategori ini melebihi aspek konten geometri pada matematika yang ada pada kurikulum.

Proses pada PISA melibatkan tujuh hal penting sebagai berikut :(1) Comunication; (2) Mathematishing; (3) Representation; (4) Reasoning and Argument; (5) Devising Strategis for Solfing Problems; (6) Using Symbolic, Formal and Techical Language and Operation; dan (7) Using Mathemtics Tools (OECD, 2019). Dalam penelitian ini lebih difokuskan pada proses komunikasi siswa.

Komunikasi merupakan rutinitas dalam berinteraksi antara dua orang atau lebih. komunikasi matematis adalah kemampuan mengekspresikan ide-ide matematika secara koheren kepada teman, guru, dan lainnya melalui bahasa lisan maupun tulisan yang disertai dengan penjelasan dan justifikasi (Ramellan, Musdi, \& Armiati, 2012). Menurut Sumarmo (Astuti \& Leonard, 2015) komunikasi matematis meliputi kemampuan siswa: 1) Menghubungkan benda nyata, gambar, dan diagram ke dalam ide matematika; 2) Menjelaskan ide, situasi dan relasi matematik secara lisan atau tulisan dengan benda nyata, gambar, grafik dan aljabar; 3) Menyatakan pristiwa sehari-hari dalam bahasa atau simbol matematika; 4) Mendengarkan, berdiskusi, dan menulis tentang matematika; 5) Membaca dengan pemahaman atau presentasi matematika tertulis; 6) Membuat konjektur, menyusun argumen, merumuskan definisi dan generalisasi; 7) Menjelaskan dan membuat pertanyaan tentang matematika yang telah terjadi.

Karena pentingnya kemampuan komunikasi yang perlu dimiliki oleh siswa, 
maka perlu bagi para pendidik untuk lebih dalam mengetahui dan menggali kemampuan komunikasi siswanya. Oleh karena itu, muncul gagasan untuk menganalisis tingkat kemampuan komunikasi matematis siswa dalam menyelesaikan soal PISA konten space dan shape.

Untuk lebih memudahkan penggalian data penelitian kemampuan komunikasi matematis siswa, maka dalam penelitian ini ditentukan indikator kemampuan komunikasi matematis siswa. Indikator kemampuan komunikasi matematis siswa dalam penelitian ini adalah (Ramellan et al., 2012) 1) Menghubungkan benda nyata, gambar atau diagram ke dalam ide matematika; 2) Menjelaskan ide, situasi atau relasi matematika secara lisan maupun tulisan; 3) Menggunakan istilah, notasi, atau simbol matematika berdasarkan strukturnya untuk menyajikan ide; dan 4) Menarik kesimpulan secara lisan maupun tulisan. Adapun rubrik penilaian untuk mengukur tingkat kemampuan komunikasi matematis adalah sebagai berikut.

Tabel 1. Rubrik Penlilain Komunikasi Matematis

\begin{tabular}{|c|c|c|}
\hline Aspek yang dinilai & Indikator & Skor \\
\hline \multirow{3}{*}{$\begin{array}{l}\text { Menghubungkan } \\
\text { benda nyata, gambar } \\
\text { dan diagram ke dalam } \\
\text { ide matematika. }\end{array}$} & $\begin{array}{l}\text { Menuliskan dan menyebutkan apa yang diketahui dan } \\
\text { ditanya sesuai dengan gambar didalam soal dengan tepat. }\end{array}$ & 6 \\
\hline & $\begin{array}{l}\text { Menuliskan atau menyebutkan apa yang diketahui dan } \\
\text { ditanya sesuai dengan gambar didalam soal dengan tepat. }\end{array}$ & 3 \\
\hline & $\begin{array}{l}\text { Tidak menuliskan dan menyebutkan apa yang diketahui dan } \\
\text { ditanya dalam soal. }\end{array}$ & 0 \\
\hline \multirow{3}{*}{$\begin{array}{lr}\text { Menjelaskan } & \text { ide, } \\
\text { situasi atau relasi } \\
\text { matematika secara } \\
\text { lisan maupun tulisan. }\end{array}$} & $\begin{array}{l}\text { Menjelaskan ide, situasi atau relasi matematika secara lisan } \\
\text { dan tulisan secara runtun dan benar. }\end{array}$ & 6 \\
\hline & $\begin{array}{l}\text { Menjelaskan ide, situasi atau relasi matematika secara lisan } \\
\text { atau tulisan secara runtun dan benar. }\end{array}$ & 3 \\
\hline & Tidak menuliskan dugaan sama sekali. & 0 \\
\hline \multirow{3}{*}{$\begin{array}{l}\text { Menggunakan istilah, } \\
\text { notasi, atau simbol } \\
\text { matematika } \\
\text { berdasarkan } \\
\text { strukturnya untuk } \\
\text { menyajikan ide. }\end{array}$} & $\begin{array}{l}\text { Menuliskan dan menyebutkan istilah, notasi, atau simbol } \\
\text { matematika apa yang digunakan dalam soal. }\end{array}$ & 6 \\
\hline & $\begin{array}{l}\text { Menuliskan atau menyebutkan istilah, notasi, atau simbol } \\
\text { matematika apa yang digunakan dalam soal. }\end{array}$ & 3 \\
\hline & $\begin{array}{l}\text { Tidak menuliskan dan menyebutkan istilah, notasi, atau } \\
\text { simbol matematika apa yang digunakan dalam soal. }\end{array}$ & 0 \\
\hline \multirow{3}{*}{$\begin{array}{l}\text { Menarik kesimpulan } \\
\text { secara lisan maupun } \\
\text { tulisan. }\end{array}$} & $\begin{array}{l}\text { Menuliskan dan menyebutkan kesimpulan akhir dengan } \\
\text { benar. }\end{array}$ & 6 \\
\hline & $\begin{array}{l}\text { Menuliskan atau menyebutkan kesimpulan akhir dengan } \\
\text { benar. }\end{array}$ & 3 \\
\hline & $\begin{array}{l}\text { Tidak dapat menuliskan dan menyebutkan kesimpulan akhir } \\
\text { dengan benar. }\end{array}$ & 0 \\
\hline
\end{tabular}


Berdasarkan latar belakang tersebut, maka fokus penelitian dalam penelitian ini adalah Bagaimanakah kemampuan komunikasi matematis siswa dalam menyelesaikan soal PISA konten space and shape?.

\section{METODE}

Pendekatan penelitian dalam penelitian ini menggunakan pendekatan kualitatif, dengan jenis penelitian deskriptif. penelitian deskriptif bertujuan untuk mendeskripsikan secara sistematik beberpa kenyataan dari sifat yang muncul secara faktual dan akurat (Tracy, 2013). Pendekatan dan jenis penelitan ini dipilih karena peneliti ingin mendeskripsikan kemampuan komunikasi matematis siswa dalam menyelesaikan soal PISA konten space and shape.

Lokasi penelitian pada penelitian ini adalah Kelas X SMA Negeri Rambipuji. Penentuan tempat dan subjek penelitian dengan beberapa pertimbangan berikut: 1) Terdapat siswa yang masih berusia 15 tahun atau baru memasuki usia 16 tahun; 2) Belum pernah dilaksanakan penelitian yang sejenis di SMA Negeri Rambipuji; 3) Peneliti ingin mengetahui kemampuan komunikasi matematis siswa kelas X SMA Negeri Rambipuji; dan 4) Belum pernah diterapkan soal PISA di sekolah. Namun soal-soal tipe HOTS sudah mulai digunakan baik dalam ujian maupun pembelajaran.

Subjek penelitian dalam penelitian ini ditentukan dengan menggunakan purposive sampling. Purposive sampling merupakan teknik pengambilan sampel yang dilandasi dengan tujuan atau pertimbangan tertentu terlebih dahulu (Creswell, 2012). Oleh karena itu, pengambilan informan didasarkan pada kriteria subjek PISA yaitu siswa yang berusia 15 tahun atau yang baru memasuki usia 16 tahun dan telah menerima soal-soal bertipe HOTS. Subyek penelitian ini adalah siswa kelas $\mathrm{X}$ MIPA 1 SMA Negeri Rambipuji yang terdiri dari 1 siswa berkemampuan matematika tinggi, dan 1 siswa berkemampuan matematika sedang. Sehingga jumlah subjek dalam penelitian ini berjumlah 2 siswa. Pemilihan dan penggolongan subjek tersebut berdasarkan nilai matematika di raport siswa semester ganjil serta saran dari guru mata pelajaran matematika.

Teknik pengumpulan data yang digunakan dalam penelitian ini adalah tes, wawancara, dan dokumentasi. Sedangkan teknik analisis data dalam penelitian ini adalah kondensasi data, penyajian data, dan verifikasi atau kesimpulan (Miles, Huberman, \& Saldana, 2014). Pada tahap kesimpulan, pengelompokan kemampuan komunikasi matematis siswa menggunakan pedoman pada tabel berikut (Teo, 2013).

Tabel 2. Pengemlompokan Kemampuan Matematis Siswa

\begin{tabular}{|c|c|c|}
\hline No & Kelas Interval & Kelompok \\
\hline 1 & $0 \leq$ Nilai $<25$ & Kurang \\
\hline 2 & $25 \leq$ Nilai $<50$ & Cukup \\
\hline 3 & $50 \leq$ Nilai $<75$ & Baik \\
\hline 4 & $75 \leq$ Nilai $<100$ & Sangat Baik \\
\hline
\end{tabular}

Untuk melakukan keabsahan data dalam penelitian ini menggunakan triangulasi. Triangulasi yang digunakan adalah triangulasi teknik. Triangulasi teknik dalam penelitian ini yaitu membandingkan data hasil tes soal PISA dengan data hasil wawancara siswa.

\section{HASIL DAN PEMBAHASAN}

Penelitian ini diawali dengan pelaksanaan tes dan dilanjutkan dengan wawancara. Soal tes yang diberikan sebanyak 2 soal yang merupakan soal PISA tahun 2012. Selanjutnya dilakukan analisis dan pemberian skor kemampuan komunikasi matematis siswa. Penskoran dilakukan pada setiap butir soal yang diberikan sesuai dengan rubrik penilaian yang ada. Adapun pengidentifikasian tahap-tahap penalaran matematis siswa pada setiap soal adalah sebagai berikut.

Identifikasi kemampuan komunikasi matematis siswa berinisial POM pada soal nomor 1

Indikator pertama dalam menentukan tingkat kemampuan komunikasi matematis siswa yaitu siswa dapat menghubungkan 
benda nyata, gambar atau diagram ke dalam ide matematika baik secara lisan maupun tulisan. Dalam indikator ini siswa dituntut dapat menuliskan dan menyebutkan apa saja yang diketahui dan ditanya dalam soal tersebut. Adapun analisis yang diperoleh dari hasil jawaban POM soal nomor 1 pada indikator pertama adalah sebagai berikut:

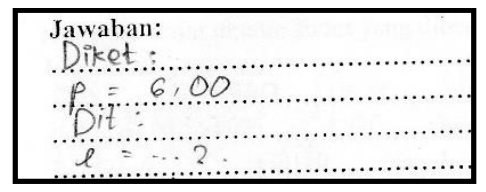

Gambar 1. Indikator 1 Soal 1

Dari hasil jawaban tes serta kutipan wawancara, dapat ditarik kesimpulan bahwa POM memenuhi indikator pertama kemampuan komunikasi matematis yaitu dapat menghubungkan benda nyata, gambar atau diagram ke dalam ide matematika baik secara lisan maupun tulisan.

Indikator kedua dalam menentukan tingkat kemampuan komunikasi matematis siswa yaitu siswa mampu menjelaskan ide, situasi dan relasi matematika secara lisan ataupun tulisan. Dalam indikator ini siswa dituntut dapat menjelaskan ide apa yang digunakan dan bagaimana dia menyelesaikan soal terssebut baik secara lisan maupun tulisan. Adapun analisis yang diperoleh dari hasil jawaban POM soal nomor 1 pada indikator kedua adalah sebagai berikut.

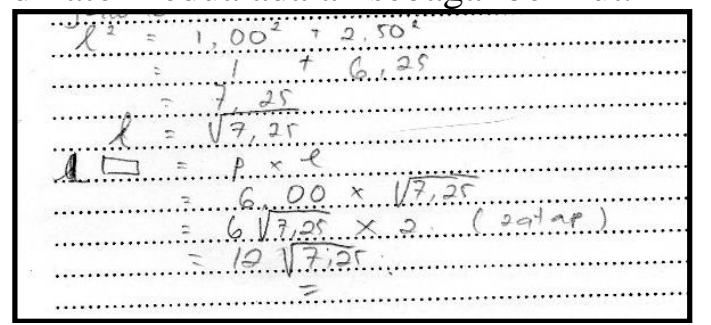

Gambar 2. Indikator II Soal 1

Hasil wawancara yang dilakukan peneliti pada siswa POM terkait dengan indikator kedua pada soal nomor 1 adalah sebagai berikut.

P : Untuk nomor 1, cara apa yang bisa kamu gunukan buat menyelesaikannya?
POM : Pakai rumus phytagoras sama rumus persegi panjang. Dan phytagorasnya digunakan untuk mencari lebarnya.

$\mathrm{P} \quad$ : Coba jelaskan cara pengerjaanmu dari nomor 1 dan 2 !

POM : Nomor 1 pakai rumus phytagoras buat nyari lebarnya yaitu sama dengan 1,00 pangkat dua ditambah 2,50 pangkat dua. Terus hasilnya akar tujuh koma dua lima. Terus cari luasnya pakai rumus panjang kali lebar sampai ketemu hasilnya dua belas akar tujuh koma dua lima.

Dari hasil jawaban dan wawancara diatas, menunjukkan bahwa siswa POM dapat menyelesaikan soal tersebut dengan benar menggunakan dugaan awalnya yaitu menggunakan rumus luas persegi panjang. Sehingga didapakan hasil akhir dari penyelesaian soal nomor 1 yaitu $12 \sqrt{7,25}$. Hal tersebut membuktikan bahwa siswa S01 dapat menyelesaikan soal tersebut dengan benar dan runtun serta mampu menjelaskannya baik melalui lisan maupun tulisan. sehingga siswa POM memenuhi indikator kedua kemampuan komunikasi matematis siswa yaitu mampu menjelaskan ide, situasi dan relasi matematika secara lisan ataupun tulisan.

Indikator ketiga dalam menentukan tingkat kemampuan komunikasi matematis siswa yaitu siswa mampu menggunakan istilah, notasi, atau simbol-simbol matematika berdasarkan strukturnya untuk menyajikan ide. Dalam indikator ini siswa dituntut dapat menggunakan istilah, notasi, atau simbol-simbol matematika untuk menyajikan ide pada soal tersebut. Adapun analisis yang diperoleh dari hasil jawaban POM soal nomor 1 pada indikator ketiga adalah sebagai berikut:

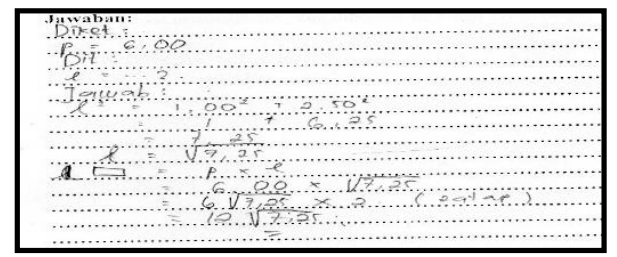

Gambar 3. Indikator III Soal 1 
Hasil wawancara yang dilakukan peneliti pada siswa POM terkait dengan indikator ketiga pada soal nomor 1 adalah sebagai berikut:

P : Coba sebutkan simbol-simbol atau notasi yang kamu gunakan!

POM : Dari nomor satu ada panjang sama lebar. Panjang pakai simbol $\mathrm{p}$ dan lebar pakai 1. soal nomor 2 ada simbol diameter pakai d besar, keliling lingkaran pakai $\mathrm{k}$ besar terus phi.

Berdasarkan hasil tes dan wawancara diatas, siswa POM dapat menggunakan simbol-simbol matematika dalam menyelesaikan soal nomor 1 . Ada beberpa simbol yang dia gunakan, diantaranya ada panjang sama lebar. Dari hasil tersebut, maka didaptkan bahwa siswa POM memenuhi indikator ketiga kemampuan komunikasi matematis.

Indikator keempat dalam menentukan tingkat kemampuan komunikasi matematis siswa yaitu siswa mampu menarik kesimpulan baik secara lisan maupun tulisan. Dalam indikator ini siswa dituntut dapat menentukan kesimpulan akhir dari soal yang dimaksud. Berdasarkan hasil analisis kemampuan penalaran pada soal nomor 1 indikator kelima, POM tidak memenuhi indikator tersebut. Hal tersebut dikarenakan POM tidak dapat menuliskan dan menyebutkan kesimpulan akhir pada soal nomor 1.

Identifikasi kemampuan komunikasi matematis siswa berinisial POM pada soal nomor 2

Indikator pertama dalam menentukan tingkat kemampuan komunikasi matematis siswa yaitu siswa dapat menghubungkan benda nyata, gambar atau diagram ke dalam ide matematika baik secara lisan maupun tulisan. Dalam indikator ini siswa dituntut dapat menuliskan dan menyebutkan apa saja yang diketahui dan ditanya dalam soal tersebut. Adapun analisis yang diperoleh dari hasil jawaban POM soal nomor 2 pada indikator pertama adalah sebagai berikut.

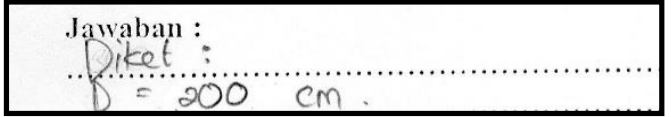

Gambar 4. Indikator I Soal 2

Kemudian hasil wawancara yang dilakukan peneliti pada siswa POM terkait dengan indikator pertama pada soal nomor 2 adalah sebagai berikut.

$\mathrm{P} \quad$ : Bisa coba sebutkan satu persatu apa saja yang diketahui dan ditanya dari soal nomor 1 , dan 2 ?

POM: Nomor 1 diketahui panjang sama dengan 6,00 yang ditanya lebar sama dengan 1,00 pangkat dua ditambah 2,50 pangkat dua, terus dicari luasnya. Nomor 2 diketahui diameternya 200 centimeter dan yang ditanya ukuran 2 sudut yang dibentuk oleh dua sayap pintu dan ditanya panjang pintunya.

Dari hasil jawaban tes dan wawancara, dapat disimpulkan bahwa siswa POM memenuhi indikator pertama kemampuan komunikasi matematis. Siswa POM menghubungkan benda nyata, gambar atau diagram ke dalam ide matematika baik secara lisan maupun tulisan. Dari hasil tersebut, siswa POM memenuhi indikator pertama pada soal nomor 1 .

Indikator kedua dalam menentukan tingkat kemampuan komunikasi matematis siswa yaitu siswa mampu menjelaskan ide, situasi dan relasi matematika secara lisan ataupun tulisan. Dalam indikator ini siswa dituntut dapat menjelaskan ide apa yang digunakan dan bagaimana dia menyelesaikan soal terssebut baik secara lisan maupun tulisan. Adapun analisis yang diperoleh dari hasil jawaban POM soal nomor 2 pada indikator kedua adalah sebagai berikut.

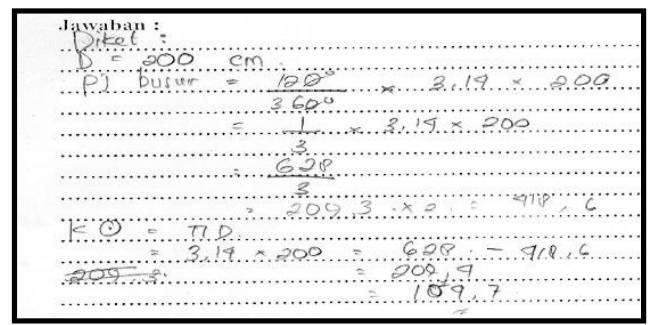

Gambar 5. Indikator II Soal 2 
Hasil wawancara yang dilakukan peneliti pada siswa POM terkait dengan indikator kedua pada soal nomor 2 adalah sebagai berikut:

P : Untuk nomor 2?

POM : Untuk nomor 2 yang pertama menggunakan konsep sudut dalam lingkarang. Sedangnkan yang satunya menggunakan panjang busur.

$\mathrm{P} \quad$ : Coba jelaskan cara pengerjaanmu dari nomor 1 dan 2 !

POM : Nomor 1 pakai rumus phytagoras buat nyari lebarnya yaitu sama dengan 1,00 pangkat dua ditambah 2,50 pangkat dua. Terus hasilnya akar tujuh koma dua lima. Terus cari luasnya pakai rumus panjang kali lebar sampai ketemu hasilnya dua belas akar tujuh koma dua lima. Nomor 2 dicari panjang busurnya dulu pakai rumus 120 per 360 dikali 3,14 dikali 200 sampai hasilnya 209,3 terus dikali dua. Terus dicari keliling lingkarannya rumusya phi dikali diameter hasilnya 628. Terus dikurangi 418,6 hasilnya 104,7.

Berdasarkan gambar 5 serta wawancara, siswa POM dapat menyelesaikan soal nomor 2 dengan menggunakan rumus atau dugaan awal yang dia tetapkan sebelumnya. Pertama siswa POM menggunakan rumus panjang busur, dengan sudut yang menghadap busur tersebut sebesar $120^{\circ}$, niliai phi 3,14 dan diameter 200. Dari proses tersebut, didapatkan panjang busurnya sebesar 418,6. Kedua, siswa S01 menggunakan rumus keliling lingkaran yaitu $\pi \times d$, dimana nilai phi nya 3,14 dan $d=200$. Hasil penyelesaian tesebut didaptkan keliling lingkaran sebesar 628. Setelah ditemukan kedua hasil tersebut, siswa POM mengurangkan hasil keliling lingkaran dengan hasil perhitungan panjang busur sehingga didapatkan hasil 104,7. Hal tersebut juga dia jelaskan ketika wawancara terkait dengan soal nomor 2. Berdasarkan hasil analisis tersebut, siswa POM memenuhi indikator kedua karena mampu menjelaskan ide matematikanya baik secara lisan maupun tulisan.

Indikator ketiga dalam menentukan tingkat kemampuan komunikasi matematis siswa yaitu siswa mampu menggunakan istilah, notasi, atau simbol-simbol matematika berdasarkan strukturnya untuk menyajikan ide. Dalam indikator ini siswa dituntut dapat menggunakan istilah, notasi, atau simbol-simbol matematika untuk menyajikan ide pada soal tersebut. Adapun analisis yang diperoleh dari hasil jawaban POM soal nomor 2 pada indikator ketiga adalah sebagai berikut.

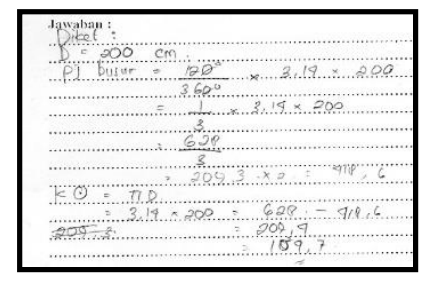

Gambar 5. Indikator III Soal 2

Hasil wawancara yang dilakukan peneliti pada POM terkait dengan indikator ketiga pada soal nomor 2 adalah sebagai berikut.

P : Coba sebutkan simbol-simbol atau notasi yang kamu gunakan!

POM : Dari nomor satu ada panjang sama lebar. Panjang pakai symbol $\mathrm{p}$ dan lebar pakai 1. soal nomor 2 ada simbol diameter pakai d besar, keliling lingkaran pakai $\mathrm{k}$ besar terus phi.

Berdasarkan hasil tes dan wawancara diatas, siswa POM dapat menggunakan simbol-simbol matematika dalam menyelesaikan soal nomor 2. Ada beberpa simbol yang dia gunakan, diantaranya ada $\mathrm{d}$ dan $\pi$. Dari hasil tersebut, maka didaptkan bahwa siswa POM memenuhi indikator ketiga kemampuan komunikasi matematis.

Indikator keempat dalam menentukan tingkat kemampuan komunikasi matematis siswa yaitu siswa mampu menarik kesimpulan baik secara lisan maupun tulisan. Dalam indikator ini siswa dituntut dapat menentukan kesimpulan akhir dari soal yang dimaksud. Berdasarkan hasil analisis kemampuan penalaran pada soal nomor 2 
indikator kelima, siswa POM tidak memenuhi indikator tersebut. Hal tersebut dikarenakan siswa POM tidak dapat menuliskan dan menyebutkan kesimpulan akhir pada soal nomor 2 .

Dari hasil analisis diatas, kesimpulan akhir dari tingkat kemampuan komunikasi matematis siswa POM pada soal nomor 1 sampai 2 dapat disimpulkan seperti pada tabel berikut.

Tabel 3. Tingkat Kemampuan Matematis POM

\begin{tabular}{|c|c|c|c|c|}
\cline { 2 - 5 } \multicolumn{1}{c|}{} & \multicolumn{2}{c|}{ Soal Nomor 1 } & \multicolumn{2}{c|}{ Soal Nomor 2 } \\
\hline $\begin{array}{c}\text { Indikato } \\
\text { r }\end{array}$ & $\begin{array}{c}\text { Hasil } \\
\text { Analisis }\end{array}$ & $\begin{array}{c}\text { Nila } \\
\text { i }\end{array}$ & $\begin{array}{c}\text { Hasil } \\
\text { Analisis }\end{array}$ & $\begin{array}{c}\text { Nila } \\
\text { i }\end{array}$ \\
\hline I & $\begin{array}{c}\text { Terpenuh } \\
\text { i }\end{array}$ & 6 & $\begin{array}{c}\text { Terpenuh } \\
\text { i }\end{array}$ & 6 \\
\hline II & $\begin{array}{c}\text { Terpenuh } \\
\text { i }\end{array}$ & 6 & $\begin{array}{c}\text { Terpenuh } \\
\text { i }\end{array}$ & 6 \\
\hline III & $\begin{array}{c}\text { Terpenuh } \\
\text { i }\end{array}$ & 6 & $\begin{array}{c}\text { Terpenuh } \\
\text { i }\end{array}$ & 6 \\
\hline IV & $\begin{array}{c}\text { Tidak } \\
\text { terpenuhi }\end{array}$ & 0 & $\begin{array}{c}\text { Tidak } \\
\text { Terpenuh } \\
\text { i }\end{array}$ & 0 \\
\hline Total & \multicolumn{2}{|c|}{18} & \multicolumn{2}{c|}{18} \\
\hline $\begin{array}{c}\text { Nilai } \\
\text { Akhir }\end{array}$ & \multicolumn{2}{|c|}{90} & \multicolumn{2}{c|}{90} \\
\hline Kategori & \multicolumn{2}{|c|}{ Sangat Baik } & \multicolumn{2}{c|}{ Sangat Baik } \\
\hline
\end{tabular}

Dari tabel 3, dapat ditarik kesimpulan bahwa POM memiliki kemampuan komunikasi matematis yang sangat baik. Hal tersebut dibuktikan dengan jawaban siswa POM pada dua soal tes menunjukkan hasil penilaian masuk dalam kategori sangat baik. Kedua soal tersebut, POM memperoleh nilai akhir nilai akhir sama yaitu 90. Berdasarkan kedua hasil akhir tersebut, POM memiliki kemamampuan komunikasi matematis sangat baik.

Identifikasi kemampuan komunikasi matematis siswa Berinisial DNL pada soal nomor 1

Indikator pertama dalam menentukan tingkat kemampuan komunikasi matematis siswa yaitu siswa dapat menghubungkan benda nyata, gambar atau diagram ke dalam ide matematika baik secara lisan maupun tulisan. Dalam indikator ini siswa dituntut dapat menuliskan dan menyebutkan apa saja yang diketahui dan ditanya dalam soal tersebut. Adapun analisis yang diperoleh dari hasil jawaban DNL soal nomor 1 pada indikator pertama adalah sebagai berikut.

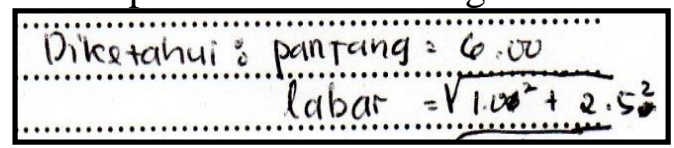

Gambar 6. Indikator 1 Soal 1

Kemudian hasil wawancara yang dilakukan peneliti pada siswa S06 terkait dengan indikator pertama pada soal nomor 1 adalah sebagai berikut:

P : Bisa coba sebutkan satu persatu apa saja yang diketahui dan ditanyadari soal nomor 1, dan 2?

DNL : Yang nomor 1 yang diketahui itu panjang persegi panjang sama lebarnya belum jadi harus mencari dulu dengan cara rumus phytagoras yang ditanyakan luas. Yang nomor 2 yang diketahui besar sudut sama diameter lingkaran pertanyaannya itu mencari berapa panjang busurnya.

Dari hasil jawaban tes serta kutipan wawancara diatas, dapat ditarik kesimpulan bahwa DNL memenuhi indikator pertama kemampuan komunikasi matematis yaitu dapat menghubungkan benda nyata, gambar atau diagram ke dalam ide matematika baik secara lisan maupun tulisan.

Indikator kedua dalam menentukan tingkat kemampuan komunikasi matematis siswa yaitu siswa mampu menjelaskan ide, situasi dan relasi matematika secara lisan ataupun tulisan. Dalam indikator ini siswa dituntut dapat menjelaskan ide apa yang digunakan dan bagaimana dia menyelesaikan soal terssebut baik secara lisan maupun tulisan. Adapun analisis yang diperoleh dari hasil jawaban DNL soal nomor 1 pada indikator kedua adalah sebagai berikut.

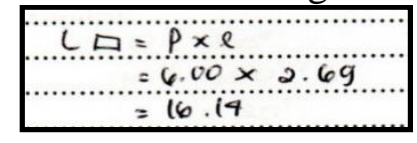

Gambar 7. Jawaban DNL soal 1 Indikator II Hasil wawancara yang dilakukan peneliti pada siswa DNL terkait dengan indikator kedua pada soal nomor 1 adalah sebagai berikut: 
P : Untuk nomor 1, cara apa yang bisa kamu gunukan buat menyelesaikannya?

DNL : Rumus luas persegi panjang

Dari hasil jawaban diatas, menunjukkan bahwa siswa DNL dapat menyelesaikan soal tersebut dengan benar menggunakan dugaan awalnya yaitu menggunakan rumus phytagoras dan luas persegi panjang. Siswa DNL melakukan penyelesaian dimulai dengan mencari lebarnya menggunakan rumus phytagoras. Setelah mendaptkan lebarnya sebesar $\sqrt{7,25}$, siswa DNL memasukkan kedalam rumus luas persegi panjang untuk mencari luas persegi panjang tersebut. Sehingga didaptkan luas dari satu atap yang berbentuk persegi panjang tersebut sebesar 16,14. Sayangnya, siswa DNL tidak mengalikannya dengan 2 karena pada soal terdapat dua atap yang harus dicari luasnya. Begitu pula dengan hasil wawancara, siswa DNL tidak menyebutkan tahap pengalian dengan 2 pada tahap terakhirnya. Bahkan, siswa DNL tidak dapat menjeleaskan penyelesaian pada soal nomor 1 ketika wawancara berlangsung.

Hal tersebut membuktikan bahwa siswa DNL dapat menyelesaikan soal tersebut dengan benar dan runtun serta mampu menjelaskannya melalui tulisan. Sehingga DNL memenuhi indikator kedua kemampuan komunikasi matematis siswa yaitu mampu menjelaskan ide, situasi dan relasi matematika secara tulisan.

Indikator ketiga dalam menentukan tingkat kemampuan komunikasi matematis siswa yaitu siswa mampu menggunakan istilah, notasi, atau simbol-simbol matematika berdasarkan strukturnya untuk menyajikan ide. Dalam indikator ini siswa dituntut dapat menggunakan istilah, notasi, atau simbol-simbol matematika untuk menyajikan ide pada soal tersebut. Adapun analisis yang diperoleh dari hasil jawaban DNL soal nomor 2 pada indikator ketiga adalah sebagai berikut.

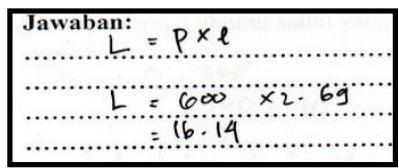

Gambar 8. Jawaban DNL soal 1 Indikator III

Hasil wawancara yang dilakukan peneliti pada DNL terkait dengan indikator ketiga pada soal nomor 2 adalah sebagai berikut.

P : Coba sebutkan symbol-simbol atau notasi yang kamu gunakan!

DNL : Yang nomor 1 simbol 1, p sama L. 1 itu lebar p itu panjang sama L itu luas. Yang nomor 2 itu ada simbol k untuk keliling $\mathrm{p}$ untuk panjang terus phi sama $r$.

Berdasarkan hasil tes dan wawancara diatas, DNL dapat menggunakan simbolsimbol matematika dalam menyelesaikan soal nomor 1 . Ada beberpa simbol yang dia gunakan, diantaranya ada $l, p$ dan $L$. Dari hasil tersebut, maka didaptkan bahwa siswa DNL memenuhi indikator ketiga kemampuan komunikasi matematis.

Indikator keempat dalam menentukan tingkat kemampuan komunikasi matematis siswa yaitu siswa mampu menarik kesimpulan baik secara lisan maupun tulisan. Dalam indikator ini siswa dituntut dapat menentukan kesimpulan akhir dari soal yang dimaksud. Berdasarkan hasil analisis kemampuan penalaran pada soal nomor 1 indikator keempat, DNL tidak memenuhi indikator tersebut. Hal tersebut dikarenakan DNL tidak dapat menuliskan dan menyebutkan kesimpulan akhir pada soal nomor 1 .

Identifikasi Kemampuan Komunikasi Matematis Siswa Berinisial DNL pada Soal Nomor 2

Indikator pertama dalam menentukan tingkat kemampuan komunikasi matematis siswa yaitu siswa dapat menghubungkan benda nyata, gambar atau diagram ke dalam ide matematika baik secara lisan maupun tulisan. Dalam indikator ini siswa dituntut 
dapat menuliskan dan menyebutkan apa saja yang diketahui dan ditanya dalam soal tersebut. Adapun analisis yang diperoleh dari hasil jawaban DNL soal nomor 2 pada indikator pertama adalah sebagai berikut.

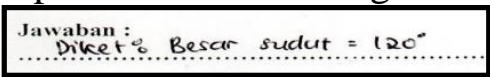

Gambar 9. Jawaban DNL soal 2 Indikator I

Kemudian hasil wawancara yang dilakukan peneliti pada siswa DNL terkait dengan indikator pertama pada soal nomor 2 adalah sebagai berikut.

P : Bisa coba sebutkan satu persatu apa saja yang diketahui dan ditanyadari soal nomor 1 dan 2?

DNL: Yang nomor 1 yang diketahui itu panjang persegi panjang sama lebarnya belum jadi harus mencari dulu dengan cara rumus phytagoras yang ditanyakan luas. Yang nomorr 2 yang diketahui besar sudut sama diameter lingkaran pertanyaannya itu mencari berapa panjang busurnya.

Dari hasil jawaban tes dan wawancara, dapat disimpulkan bahwa DNL memenuhi indikator pertama kemampuan komunikasi matematis. DNL menghubungkan benda nyata, gambar atau diagram ke dalam ide matematika baik secara lisan maupun tulisan. Dari hasil tersebut, DNL memenuhi indikator pertama pada soal nomor 2 .

Indikator kedua dalam menentukan tingkat kemampuan komunikasi matematis siswa yaitu siswa mampu menjelaskan ide, situasi dan relasi matematika secara lisan ataupun tulisan. Dalam indikator ini siswa dituntut dapat menjelaskan ide apa yang digunakan dan bagaimana dia menyelesaikan soal terssebut baik secara lisan maupun tulisan. Adapun analisis yang diperoleh dari hasil jawaban DNL soal nomor 2 pada indikator kedua adalah sebagai berikut.

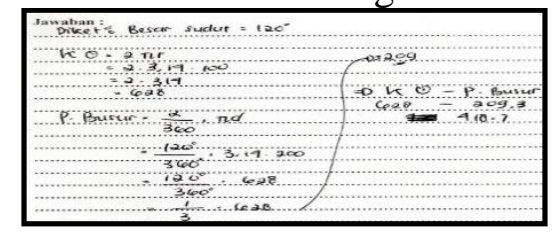

Gambar 10. Jawaban DNL Soal 2 Indikator
Hasil wawancara yang dilakukan peneliti pada DNL terkait dengan indikator kedua pada soal nomor 2 adalah sebagai berikut.

$\mathrm{P} \quad$ : Untuk nomor 2?

DNL : Pakai panjang busur tapi harus diketahui keliling lingkaran dulu.

Berdasarkan gambar 10 diatas, DNL dapat menyelesaikan soal nomor 2 dengan menggunakan rumus atau dugaan awal yang dia tetapkan sebelumnya. Pertama, DNL menggunakan rumus keliling lingkaran yaitu $\pi \times d$, dimana nilai phi nya 3,14 dan $d=$ 200. Hasil penyelesaian tesebut didapatkan keliling lingkaran sebesar 628. Selanjutnya, siswa S06 menggunakan rumus panjang busur, dengan sudut yang menghadap busur tersebut sebesar $120^{\circ}$, niliai phi 3,14. Dari proses tersebut, didapatkan panjang busurnya sebesar 209,3. Setelah ditemukan kedua hasil tersebut, DNL mengurangkan hasil keliling lingkaran dengan hasil perhitungan panjang busur sehingga didapatkan hasil 418,7. Sayangnya, DNL tidak mengalikan hasil panjang busurnya dengan 2, karena terdapat 2 busur pada soal tersebut. Sehingga hasil yang didaptkan dari penyelesaian soal tersebut salah. Begitu pula dengan hasil wawancara dengan DNL terkait penyelesaiannya soal nomor 2. DNL tidak dapt menjeleskan penyelesaian yang dia gunakan pada saat wawancara. Walaupun dia tidak dapat menjeleskan, DNL tetep memenuhi indikator kedua kemampuan komunikasi matematis siswa.

Indikator ketiga dalam menentukan tingkat kemampuan komunikasi matematis siswa yaitu siswa mampu menggunakan istilah, notasi, atau simbol-simbol matematika berdasarkan strukturnya untuk menyajikan ide. Dalam indikator ini siswa dituntut dapat menggunakan istilah, notasi, atau simbol-simbol matematika untuk menyajikan ide pada soal tersebut. Adapun analisis yang diperoleh dari hasil jawaban S06 soal nomor 2 pada indikator ketiga adalah sebagai berikut. 


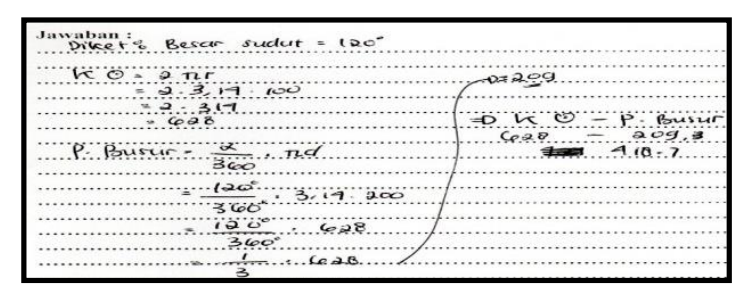

Gambar 11. Jawaban DNL Soal 2 Indikator 3

Hasil wawancara yang dilakukan peneliti pada DNL terkait dengan indikator ketiga pada soal nomor 2 adalah sebagai berikut.

P : Coba sebutkan symbol-simbol atau notasi yang kamu gunakan!

DNL : Yang nomor 1 simbol 1, p sama L. 1 itu lebar p itu panjang sama L itu luas. Yang nomor 2 itu ada simbol k untuk keliling $\mathrm{p}$ untuk panjang terus phi sama $r$.

Berdasarkan hasil tes dan wawancara diatas, DNL dapat menggunakan simbolsimbol matematika dalam menyelesaikan soal nomor 2. Ada beberpa simbol yang dia gunakan, diantaranya ada $k, p$ dan $\pi$. Dari hasil tersebut, maka didaptkan bahwa siswa S06 memenuhi indikator ketiga kemampuan komunikasi matematis.

Indikator keempat dalam menentukan tingkat kemampuan komunikasi matematis siswa yaitu siswa mampu menarik kesimpulan baik secara lisan maupun tulisan. Dalam indikator ini siswa dituntut dapat menentukan kesimpulan akhir dari soal yang dimaksud. Berdasarkan hasil analisis kemampuan penalaran pada soal nomor 2 indikator keempat, DNL tidak memenuhi indikator tersebut. Hal tersebut dikarenakan DNL tidak dapat menuliskan dan menyebutkan kesimpulan akhir pada soal nomor 2.

Dari hasil analisis diatas, kesimpulan akhir dari tingkat kemampuan komunikasi matematis siswa berinisial DNL pada soal nomor 1 dan 2 dapat disimpulkan seperti pada tabel berikut.
Tabel 4. Tingkat Kemampuan Matematis DNL

\begin{tabular}{|c|c|c|c|c|}
\cline { 2 - 5 } \multicolumn{1}{c|}{} & \multicolumn{2}{c|}{ Soal Nomor 1 } & \multicolumn{2}{c|}{ Soal Nomor 2 } \\
\hline $\begin{array}{c}\text { Indikato } \\
\text { r }\end{array}$ & $\begin{array}{c}\text { Hasil } \\
\text { Analisis }\end{array}$ & $\begin{array}{c}\text { Nila } \\
\text { i }\end{array}$ & $\begin{array}{c}\text { Hasil } \\
\text { Analisis }\end{array}$ & $\begin{array}{c}\text { Nila } \\
\text { i }\end{array}$ \\
\hline I & Terpenuhi & 6 & $\begin{array}{c}\text { Terpenuh } \\
\text { i }\end{array}$ & 3 \\
\hline II & Terpenuhi & 3 & $\begin{array}{c}\text { Terpenuh } \\
\text { i }\end{array}$ & 3 \\
\hline IV & $\begin{array}{c}\text { Terpenuhi } \\
\text { II }\end{array}$ & 6 & $\begin{array}{c}\text { Terpenuh } \\
\text { i }\end{array}$ & 6 \\
\hline Tidak & 0 & $\begin{array}{c}\text { Tidak } \\
\text { Terpenuh } \\
\text { terpenuhi }\end{array}$ & 0 \\
\hline $\begin{array}{c}\text { Nilai } \\
\text { Akhir }\end{array}$ & \multicolumn{2}{|c|}{15} & \multicolumn{2}{c|}{12} \\
\hline Kategori & \multicolumn{2}{|c|}{ Sangat Baik } & \multicolumn{2}{c|}{ Baik } \\
\hline
\end{tabular}

Dari tabel 4, dapat ditarik kesimpulan bahwa DNL memiliki kemampuan komunikasi matematis yang baik. Hal tersebut dibuktikan dengan jawaban DNL pada dua soal tes menunjukkan hasil penilaian masuk dalam kategori baik. kedua soal tersebut, DNLmemperoleh nilai akhir nilai akhir 75 pada soal nomor 1 , nilai akhir 60 pada soal nomor 2 .

Dari hasil analisis data tersebut di atas didapatkan tingkat kemampuan komunikasi matematis yang berbeda antara kedua siswa yang memiliki kemampuan matematika tinggi dan sedang. Berikut hasil analisis kemampuan komunikasi matematis kedua siswa dalam menyelesaikan soal PISA.

Tabel 5. Hasil Kemampuan Komunikasi Matematis

\begin{tabular}{|c|c|c|c|c|}
\hline \multirow[b]{2}{*}{ Siswa } & \multicolumn{2}{|c|}{ Nilai soal } & \multirow{2}{*}{$\begin{array}{c}\text { Rata- } \\
\text { rata }\end{array}$} & \multirow[b]{2}{*}{ Kategori } \\
\hline & $\begin{array}{c}\text { Nomor } \\
1\end{array}$ & Nomor 2 & & \\
\hline POM & 90 & 90 & 90 & $\begin{array}{c}\text { Sangat } \\
\text { baik }\end{array}$ \\
\hline DNL & 75 & 60 & 67,5 & Baik \\
\hline
\end{tabular}

Dari tabel 5 di atas menunjukkan bahwa tingkat kemampuan komunikasi matematis kedua subjek menunjukkan hasil yang berbeda. Kemampuan komunikasi matematis siswa dengan kemampuan matematika tinggi yaitu POM, berada pada kategori sangat baik. POM hampir memenuhi seluruh indikator kemampuan komunikasi matematis. Hanya saja dia tidak 
dapat menyampaikan kesimpulan akhir sehingga dia tidak memenuhi indikator keempat kemampuan komunikasi matematis.

Sedangkan untuk DNL, rata-rata mampu memenuhi indikator pertama hingga ketiga kemampuan komunikasi matematis. Hanya saja pada soal 1 indikator II DNL tidak menyebutkan tahap pengalian dengan 2 pada tahap terakhirnya. Bahkan, DNL tidak dapat menjelaskan penyelesaian pada soal nomor 1 ketika wawancara berlangsung. Selain itu, pada soal nomor 2 indikator 1 dan 2 DNL tidak dapat menjawab dengan sempurna sehingga nilai yang diperoleh berdasarkan kategori kemampuan komunikasi matematis siswa tidak maksimal. Hasilnya DNL yang memiliki kemampuan matematika sedang, kemampuan komunikasi matematisnya berada pada kategori baik.

\section{SIMPULAN}

Berdasarkan hasil dan pembahasan di atas, dapat disimpulkan bahwa: 1) siswa dengan kemampuan matematika tinggi yaitu POM dapat menyelesaikan soal PISA dengan kriteria hampir memenuhi seluruh indikator kemampuan komunikasi matematis. Hanya saja dia tidak dapat menyampaikan kesimpulan akhir sehingga dia tidak memenuhi indikator keempat kemampuan komunikasi matematis. Ini berarti bahwa siswa yang memeliki kemampuan matematika tinggi, kemampuan komunikasi matematisnya berada pada kategori sangat baik; 2) siswa dengan kemampuan matematika sedang yaitu DNL dapat menyelesaikan soal PISA dengan rata-rata mampu memenuhi indikator pertama hingga ketiga kemampuan komunikasi matematis, namun terdapat beberapa indikator yang tidak dijawab dengan sempurna. Ini berarti bahwa siswa yang memiliki kemampuan matematika sedang, kemampuan komunikasi matematisnya berada pada kategori baik.

\section{DAFTAR PUSTAKA}

Astuti, A., \& Leonard. (2015). Peran

Kemampuan Komunikasi Matematika Terhadap Prestasi Belajar Siswa.

Formatif, 2(2), 102-110.
Creswell, J. W. (2012). Educational research : planning, conducting, and evaluating quantitative and qualitative research - 4th ed. Boston: Pearson Education, Inc.

Miles, M. B., Huberman, A. M., \& Saldana, J. (2014). Qualitative Data Analysis: A Methods Sourcebook (Third Edit). United States of America: SAGE Publications, Inc.

OECD. (2016). PISA 2015 Assessment and Analytical Framework: Science, Reading, Mathematic and Financial Literacy. Retrieved from http://dx.doi.org/10.1787/97892642554 25-en

OECD. (2017). PISA for Development Assessment and Analytical Framework: Reading, Mathematics and Science - Preliminary Version. Paris: OECD Publishing.

OECD. (2019). PISA 2018 Assessment and Analytical Framework. Retrieved from https://doi.org/10.1787/b25efab8-en

Ramellan, P., Musdi, E., \& Armiati. (2012). Kemampuan Komunikasi Matematis dan Pembelajaran Interaktif. Pendidikan Matematika, 1(2), 77-82.

Teo, T. (2013). Handbook of Quantitative Methods for Educational Research. Rotterdam: Sense Publishers.

Tracy, S. J. (2013). Qualitative Research Methods (First Edit). United Kingdom: Wiley-Blackwell, John Wiley \& Sons, Ltd., Publication.

\section{PROFIL SINGKAT}

Mohammad Kholil, lahir di Banyiwangi, 13 Juni 1986 dari pasangan Abdul Mu'in (Alm.) dan Siti Maimunah (Almh.). Pendidikan sarjana di tempuh di Universitas Brawijaya Malang Jurusan Matematika dan lulus pada tahun 2009. Sedangkan untuk Pendidikan Pascasarjana S2 Pendidikan Matematikan ditempuh di Universitas Negeri Malang dan lulus pada tahun 2011. Pada tahun 2015 mulai mengajar di IAIN Jember sampai sekarang. 